\title{
Serine Conjugates of Chlorophyll and Bacteriochlorophyll: Photocytotoxicity in vitro and Tissue Distribution in Mice Bearing Melanoma Tumors
}

\author{
V. Rosenbach-Belkin', L. Chen ${ }^{2}$, L. Fiedor', I. Tregub', F. Pavlotsky ${ }^{3}$, V. Brumfeld', \\ Y. Salomon ${ }^{2}$ and A. Scherz*1 \\ ${ }^{1}$ Department of Biochemistry and \\ 2Department of Biological Regulation, The Weizmann Institute of Science, Rehovot, Israel and \\ 3Department of Dermatologyt, Sheba Medical Center, Tel-Hashomer, Israel
}

Received 26 February 1996; accepted 27 March 1996

\section{ABSTRACT}

Chlorophyll (Chl) and bacteriochlorophyll (Bchl) have been made water soluble by transesterfication with serine (Ser) at the propionyl residue and tested as potential reagents for photodynamic therapy (PDT). Photocytotoxicity of the conjugates Chl-Ser and Bchl-Ser in M2R mouse melanoma was tested in cell cultures. Tissue uptake and clearance of the photosensitizers in CD1 nude and C57BI mice implanted with $M 2 R$ tumors are described. Photocytotoxicity in cell cultures was determined microscopically and by $\left[{ }^{3} \mathrm{H}\right]$ thymidine incorporation. The $\mathrm{LD}_{50}$ values in vitro were $0.05-0.1 \mu M$ for both sensitizers while that of the commercially available hematoporphyrin derivative (HPD, Photosan) was over 100 times higher for the same light intensity $\left(45 \mathrm{~mW} / \mathrm{cm}^{2}\right)$. Pigment concentrations were determined fluorometrically in acetone extracts of the tissues of interest at different times after intraperitoneal injection of $20 \mathrm{mg}$ pigment $/ \mathrm{kg}$ body weight. The distribution pattern of Chl-Ser in the different tissues resembled that reported for Photofrin, chlorin and bacteriochlorin derivatives. Clearance from normal tissues was essentially completed within $16 \mathrm{~h}$ for BchlSer and $72 \mathrm{~h}$ for Chl-Ser with mean half-lives $\left(t_{1 / 2}\right)$ of about 2 and $7 \mathrm{~h}$, respectively. In contrast, the clearance rates of these pigments and their metabolites from melanoma tumor tissue were significantly longer: $t_{1 / 2}=20 \mathrm{~h}$ for Chl-Ser and $15 \mathrm{~h}$ for Bchl-Ser and metabolites. The clearance rates showed biphasic or single exponential decay patterns in normal tissues and in tumors, respectively. Cumulatively the high phototoxicity, simple mode of delivery and fast tissue clearance rates reported here suggest that polar conjugates of $\mathrm{Chl}$ and $\mathrm{Bchl}$ promise to be highly effective PDT reagents.

\footnotetext{
*To whom correspondence should be addressed at: The Department of Biochemistry, Weizmann Institute of Science, Rehovot 76100 , Israel. Fax: 97289344118 ;

e-mail: bcscherz@weizmann.weizmann.ac.il.

of 1996 American Society for Photobiology $0031-8655 / 96 \quad \$ 5.00+0.00$
}

\section{INTRODUCTION}

Among the major considerations for introducing new photodynamic therapy (PDT) $\dagger$ agents are their spectral properties, tissue levels attained and their uptake and clearance rates. The last two factors are suggested to depend upon the hydrophilicity/hydrophobicity of the photodynamic reagent (1). Whereas increased hydrophobicity is believed to enhance the pigment's occlusion in the transformed cells. it complicates their delivery and slows down their clearance from normal tissues.

Chlorophylls (Chl) and bacteriochlorophylls (Bchl) are natural pigments with high optical extinction coefficients in the $\sim 660 \mathrm{~nm}$ and $\sim 780 \mathrm{~nm}$ bands, respectively. In the second wavelength domain. light penetration depth is approximately three times that attained at $630 \mathrm{~nm}$. the wavelength currently used in clinics for photosensitization of Photofrin (2-5). Chlorophyll and Bchl have good yields of excited triplet state with lifetimes similar to those observed for hematoporphyrin derivative (HPD) $(30-70 \%$, D. Leupold,personal communication) (5-7) and consequently show antitumor activity in vivo after delivery in detergent micelle or liposome vehicles (8). These pigments were also reported to clear from mouse tissues within a few days, significantly faster than Photofrin, thus eliminating potential long-term cutaneous phototoxicity (8-10). Derivatives of $\mathrm{Chl}$ and $\mathrm{Bchl}$ with enhanced hydrophobicity were prepared and some of them were reported to have high therapeutic potential $(1,11,12)$. At the same time, the hydrolysis product of 2-(1hexyloxyethyl)-2-devinyl-methyl pyropheophorbide a seems to be a good photosensitizer despite its much higher hydrophilicity $(11,13)$.

Because the spectral characteristics of $\mathrm{Chl}$ and $\mathrm{Bchl}$ are determined by their macrocycle, it was realized that modifications of peripheral groups that are not conjugated to the macrocycle may further enhance their hydrophilicity while

$\rightarrow$ Abbreviations: Bchl, bacteriochlorophyll; Bphe. bacteriopheophytin; Chl, chlorophyll; Chlase, chlorophylase; HPD, hematoperphyrin derivative: i.p., intraperitoneal; PDT, photodynamic therapy; Phe, pheophytin; PID, propidium iodide (2.7-diamino-9phenyl-10-[diethylaminopropyl]-phenathridium iodide; Ser, serine. 
retaining their photodynamic activity as in the cases of chlorins, pheophorbides or purpurins $(1,11-19)$. Indeed, hydrolysis of the phytol chain of $\mathrm{Chl}$ a and $\mathrm{Bchl}$ a enhanced their solubility in aqueous media by several orders of magnitude. Further increase was observed upon esterification of the propionic side chain with polar amino acid residues such as serine and tyrosine (20), while the optical properties and quantum yield for triplet state formation of the $\mathrm{Chl} / \mathrm{Bchl}$ conjugates were found similar to those of native $\mathrm{Chl} / \mathrm{Bchl} \mathrm{mol}-$ ecules (6). Furthermore, the new compounds showed photodynamic activity both in vitro (21) and in vivo (20.22.23).

The enhanced hydrophilicity of the $\mathrm{Chl} / \mathrm{Bchl}$ derivatives may strongly affect their uptake and retention times in tumor and normal tissues and consequently the treatment protocol. Furthermore, it may strongly affect their distribution within the target cells and hence, their photodynamic activity. Therefore, we set out to: (1) compare the photodynamic activity of Chl-Ser and Bchl-Ser with those of commercial HPD, using melanoma cell cultures and (2) determine the tissue distribution of Chl-Ser and Bchl-Ser and their metabolites (when present) at different time intervals after administration to melanoma-bearing mice.

\section{MATERIALS AND METHODS}

Photosensitizers. The Chl-Ser and Bchl-Ser were prepared from the natural pigments $\mathrm{Chl}$ a and $\mathrm{Bchl}$ a, respectively, using Melia aredarach L., China tree chlorophylase (Chlase) (24) as previously described by us $(20,25)$. 1-Methyl ester serine hydrochloride $(400 \mathrm{mg}$. Sigma) and $70 \mathrm{mg}$ ascorbic acid (Merck) were dissolved in $9 \mathrm{~mL}$ of water. Using $10 \mathrm{M} \mathrm{KOH}$ aqueous solution, the $\mathrm{pH}$ of the serine solution was adjusted to 7.7 and $1 \mathrm{~mL}$ of $0.5 M$ sodium phosphate buffer ( $\mathrm{pH} \mathrm{7.7)} \mathrm{was} \mathrm{added} \mathrm{to} \mathrm{maintain} \mathrm{the} \mathrm{pH}$ during the reaction. Approximatcly $80 \mu \mathrm{l}$ of Triton $\mathrm{X}-100$ are added to achicve a final detergent concentration of $0.8 \%(\mathrm{vol} / \mathrm{vol})$. In $6 \mathrm{~mL}$ of this solution, $200 \mathrm{mg}$ of Chlase acetone powder was homogenized using a Polytron homogenizer. The enryme suspension was sonicated with 20 mg of solid Bchl a/Chl a, saturated with argon and incubated in the dark for 7 h at $37^{\circ} \mathrm{C}$ while stirring. For purification the reaction mixture was filtered under vacuum and the residual pigments were washed from the filter paper with acetone. The combined filtrates were then saturated with $\mathrm{NaCl}$ and the pigments were extracted with diethyl ether. After drying over $\mathrm{NaCl}$, the solvents were cvaporated under vacuum. Any water left was removed by lyophilization. The residue was dissolved in acetone and subjected to column chromatography on CM-Sepharose equilibrated with acetone. The column was washed with acetone to elute unreacted material and then with $5 \%$ and $7 \%$ methanol (vol/vol) in acetone to elute bacteriochlorophillide/chlorophyllide and bacteriopheophorbide/pheophorbide. The Bchl-Ser/Chl-Ser were then eluted with $25 \%$ methanol in acetone at a yield of $70-80 \% \mathrm{Bchl}-\mathrm{Ser} / \mathrm{Ch}$-Ser relative to the starting $\mathrm{Bchl} / \mathrm{Chl}$. The solvent was evaporated and the solid pigments stored under argon at $-20 \mathrm{C}$ in the dark until used.

The HPD was the commercially available Photosan-3, supplied at a concentration of $3.3 \mathrm{mg} / \mathrm{mL}$ in isotonic NaCl by eelab. Seehof GmbH D-2244 Wesselburenerkoog. Germany, kindly given to us by Dr. J. Moser.

Cell culture. The M2R mouse melanoma cells were cultured as monolayers in Dulbeco's modified Eagle's medium/F 12 containing $25 \mathrm{~m} M$ HEPES pH 7.4, 10\% fetal bovine serum, glutamine $2 \mathrm{mM}$, penicillin $0.06 \mathrm{mg} / \mathrm{mL}$ and streptomycin $0.1 \mathrm{mg} / \mathrm{mL}$. at $37^{\circ} \mathrm{C}$ in a humidified atmosphere of $8 \% \mathrm{CO}_{2}$ as previously described (26)

Cell photocytotoxicity studies. The M2R mouse melanoma cells $\left(1 \times 10^{5}\right.$ cells/well $)$ were cultured in 24 well microplates and grown for $24 \mathrm{~h}$ to about $2 \times 10^{5}$ cells/well, approximately $70-80 \% \mathrm{con}$ fluency. The Chl-Ser or Bchl-Ser were dissolved in culture medium and dispersed by sonication. Photosan was diluted to its final concentration in culture medium. The medium was replaced with serumfree medium and cells were incubated in the dark with the desired concentration of photosensitizers. Following $2 \mathrm{~h}$ of incubation the cells were irradiated at room temperature for $5 \mathrm{~min}$ from the bottom of the plate. The medium was replaced by serum containing medium and the culture plates were placed back in the incubator for $24 \mathrm{~h}$. Cytotoxic efficiency in the cell culture was determined by (i) microscopic examination of cell morphology, (ii) fluorescence micros copy of cells following treatment with vital stain (propidium iodide [PID] [2.7-diamino-9-phenyl-10-(diethylaminopropyl)-phenathridinium iodide methiodide) , which selectively accumulates in nuclei of damaged cells (27) and (iii) $\left[{ }^{3} \mathrm{H}\right]$ thymidine incorporation as further described below. Control experiments included (1) untreated cells kept in the dark, (2) untreated cells illuminated and (3) cells treated with the drug but kept in the dark.

Light source. The light source for irradiation was a home-built $250 \mathrm{~W}$ halogen lamp focused through a $10 \mathrm{~cm}$ water filter on a glass support and fitted with a cut-off filter that blocked light under 550 $\mathrm{nm}$ in the case of Photosan as a photosensitizer or under $610 \mathrm{~nm}$ for cells treated with Chl-Ser and Bchl-Ser. The light dose was ad-

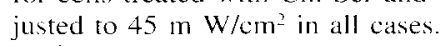

${ }^{3}$ H/thwidine incorporation. Twenty four hours after PDT, cell cultures were pulsed with $1 \mu \mathrm{Ci} / \mathrm{mL}\left[{ }^{3} \mathrm{H}\right.$ thymidine for $2 \mathrm{~h}$ at $37^{\circ} \mathrm{C}$ Cultures were then washed twice with phosphate-buffered saline, treated with $7.5 \%$ cold trichloroacetic acid for $30 \mathrm{~min}$ at $4 \mathrm{C}$ and washed twice with ethanol. Sodium hydroxide $(1 \mathrm{~N}, 300 \mu \mathrm{L} / \mathrm{well})$ was added and the plates were kept for $10 \mathrm{~min}$ at $37^{\circ} \mathrm{C}$. Samples of $100 \mu \mathrm{L}$ were transferred to scintillation vials, neutralized with 100 $\mu \mathrm{L} 1 \mathrm{~N} \mathrm{HCl}$ and radioactivity was counted by liquid scintillation counting in $4 \mathrm{~mL},(20: 8[\mathrm{vol} / \mathrm{vol}])$ xylene scintillator lumax mixture according to Chen et al. (28).

Animals. All studies were performed on adult C57Bl males $(25$ $\pm 3 \mathrm{~g})$, CDl nude male $(35 \pm 3 \mathrm{~g})$ or female $(30 \pm 3 \mathrm{~g})$ mice.

Tumor model. The M2R mouse melanoma cells were maintained as monolayers in tissue culture as described previously (26). Tumors were implanted by subcutaneous injection of $1 \times 10^{6}$ cells $/ 0.1 \mathrm{~mL}$ saline on the back of the mouse as described previously (29). In approximately 3-5 weeks, the dark melanotic tumors became visible as solid confined structures with an average diameter of $5-10 \mathrm{~mm}$.

Administration of pigment. The dried pigment aliquot was taken up in a small volume of ethanol and diluted $10 \times$ in normal saline. The pigments, either (hl-Ser or Bchl-Ser $(20 \mathrm{mg} / \mathrm{kg}$ body weight) were administered intraperitoneally (i.p.).

Analysis of tissue distribution. At different times after injection, the animals were sacrificed by $\mathrm{CO}_{2}$ intoxication and tissue samples (epididymal fat, intestine, striated muscle, blood and skin), intacl organs (heart, liver, lung, spleen, kidney, brain, testes) and the M2R tumor $(0.2-1.0 \mathrm{~g})$ were excised, frozen on dry ice and stored at $-20^{\circ} \mathrm{C}$ until analysis for pigment content was performed.

Determination of pigment concentration in the tissues. The frozen tissue samples were weighed and homogenized with a Polytron (Kinematica GmbH or Ultra-Turrax) in ice-cold acclone under subdued light and subsequently centrifuged at $14500 \mathrm{~g}$ for $15 \mathrm{~min}$ at $4 \%$. The pigment concentrations in the supernatant were estimated by fluorescence spectroscopy using an SLM 8000 spectrofluorometer (Aminco) in a photon-counting mode and expressed per gram of wet weight tissue. The Chl-Ser samples were excited at $416 \mathrm{~nm}$ with 4 $\mathrm{nm}$ excitation and cmission slits and the fluorescence was monitored at $672 \mathrm{~nm}$. The Bchl-Ser samples were excited at $370 \mathrm{~nm}$ with 8 $\mathrm{nm}$ slits and the fluorescence was monitored at $790 \mathrm{~nm}$. The pigment concentration was determined from the fuorescence intensity data by using calibration plots, obtained by direct measurements of the fluorescence from a series of standard solutions of the analyzed pigment in $2.5 \% \mathrm{H}_{2} \mathrm{O} /$ acetone. The control extracts prepared from identical tissue samples obtained from untreated mice were used for baseline measurements. The absorption spectra of the different samples recorded on a Spectronics 1201 spectrophotometer provided information concerning the metabolic stability of the injected pigment.

\section{RESULTS AND DISCUSSION}

\section{Photocytotoxicity of $\mathrm{Chl} / \mathrm{Bchl}$-Ser in M2R mouse melanoma cell cultures}

Microscopic evaluation. In order to evaluate light-dependent cytotoxicity of Chl-Ser we first treated M2R melanoma cell 

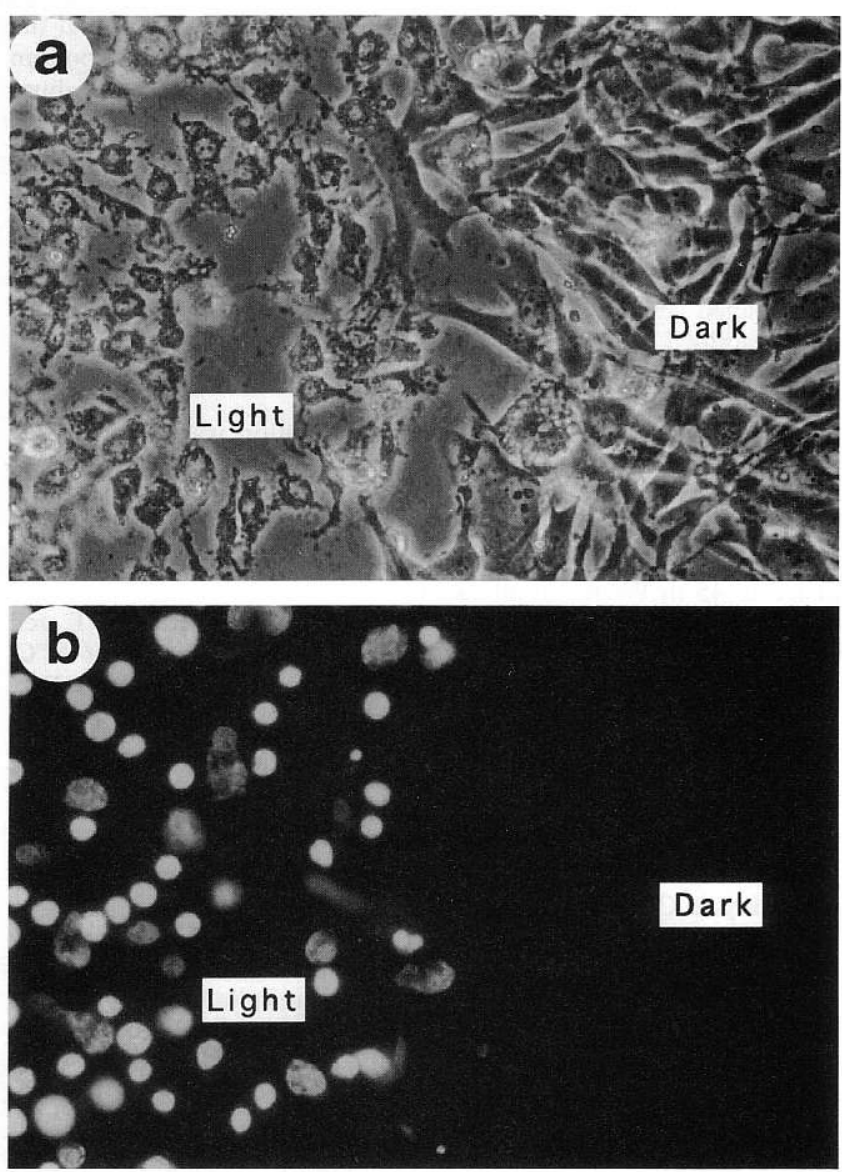

Figure 1. Photocytotoxicity of Chl-Ser: microscopic determination. Phase-contrast (a) or fluorescence microscopy (b) of one image of $\mathrm{M} 2 \mathrm{R}$ cells monolayers incubated for $1 \mathrm{~h}$ with $1 \mu M \mathrm{Chl}-\mathrm{Ser}$ and irradiated for $5 \mathrm{~min}$. Indicated are the unilluminated area covered with aluminum foil (Dark) and the illuminated area (Light). Magnification $900 \times$ using a Ziess Axiovert 35 inverted microscope with rhodamine optics. Cells in the dark area have a normal shape (a) and exclude the vital stain PID (b). Cells in the illuminated area (Light) appear damaged (a) and their nuclei become stained with PID (b).

cultures with $1 \mu M$ of the pigment for $1 \mathrm{~h}$. Following replacement of the medium, the experimental culture plates were illuminated with a half area covered with aluminum foil (as dark control) and further kept under normal culture conditions for $24 \mathrm{~h}$ (Fig. 1a,b). Microscopic examination of the cultures indicated that cells in the illuminated regions (marked "Light") became partially detached and the remaining cells appeared morphologically damaged (Fig. 1a, phase-contrast micrograph, light area) and became all positively stained by PID (Fig. 1b fluorescence micrograph, light area). In contrast, cells in the shadowed area (served as "Dark" controls) appeared normal (Fig. 1a, dark area) and excluded the dye (Fig. 1b dark area). Cells in illuminated untreated controls appeared identical to untreated or darktreated control cultures.

$\left[{ }^{3} H\right]$ thymidine incorporation. In order to quantify the light-dependent cytotoxicity of the new $\mathrm{Chl}$ derivatives, cell cultures were incubated at increasing concentrations of ChlSer or Bchl-Ser (Fig. 2) and the effects on $\left[{ }^{3} \mathrm{H}\right]$ thymidine incorporation were determined. In comparison we also de-

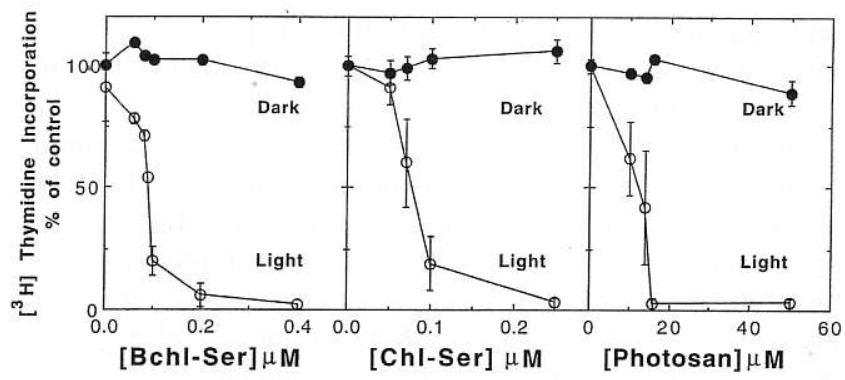

Figure 2. Photocytotoxicity of Chl-Ser, Bchl-Ser and Photosan: M2R cell survival determined by $\left[{ }^{3} \mathrm{H}\right]$ thymidine incorporation. $\left[{ }^{3} \mathrm{H}\right]$ thymidine incorporation in M2R cells following treatment with the indicated photosensitizer concentrations (Bchl-Ser, Chl-Ser and Photosan) in the dark or after illumination ( $5 \mathrm{~min}$ ) is shown. Cell survival is given as $\left[{ }^{3} \mathrm{H}\right]$ thymidine incorporation $(2 \mathrm{~h}$ pulse) performed $24 \mathrm{~h}$ after photodynamic treatment relative to untreated controls. Values are the mean \pm SD of 8,2 and 7 experiments, respectively, performed by duplicate determinations each.

termined photocytotoxicity of Photosan under the same conditions (Fig. 2). It can be seen that cytotoxicity of both pigment derivatives (Chl-Ser and Bchl-Ser) is absolutely light and dose dependent. The effective concentration range is in the submicromolar range, over 100 times lower then that displayed by HPD. Noteworthy is the fact that the $\mathrm{LD}_{50}$ values of the water-soluble $\mathrm{Chl}$ and $\mathrm{Bchl}$ conjugates are lower by an order of magnitude from values reported for the analogues hydrophobic methyl esters of Bchl and its free acid analog bacteriopheophytin (Bphe) applied to M2R mouse melanoma cell cultures (30).

\section{Biodegradation of Chl-Ser}

The absorption spectra of acetone extracts obtained from some of the tissues $12-72 \mathrm{~h}$ after injection were characterized by two optical transitions at 510 and $545 \mathrm{~nm}$ in addition to the typical $\mathrm{Chl}$ absorption profile. These additional bands appeared similar to those of pheophytin a (Phe a), the demetallized derivative of $\mathrm{Chl}$ a (31), which has its lowest energy transition at wavelengths similar to that of Chl-Ser. This result suggested that small amounts of Chl-Ser were converted to the Phe a derivative in vivo. The Phe a derivative by itself is likely to be photodynamically active (8). Therefore fluorometric determinations of total pigment concentrations were performed by excitation at $416 \mathrm{~nm}$ where equal concentrations of both pigments (Chl-Ser and Phe-Ser) maintain the same fluorescence peak intensities at $672 \mathrm{~nm}$.

\section{Distribution of Chl-Ser in mouse tissues}

The Chl-Ser distribution in tissues of CD1 mice was studied between 2 to $72 \mathrm{~h}$ after i.p. injection of $20 \mathrm{mg}$ Chl-Ser $/ \mathrm{kg}$ body weight (Fig. 3, Table 1). The time-dependent changes in tissue pigment concentration indicated that maximal levels of Chl-Ser in most tissues were reached within $2 \mathrm{~h}$, the earliest time point sampled after injection. Much slower uptake rates were seen in skin and tumor where pigment peak levels reached maxima only at 12 and $5 \mathrm{~h}$ after injection, respectively. The relative distribution of Chl-Ser among different tissues in nude mice is qualitatively similar to that reported for Photofrin (32) and other sensitizers $(13,33)$. Thus, kidney and the reticuloendothelial cell-containing organs like liver 

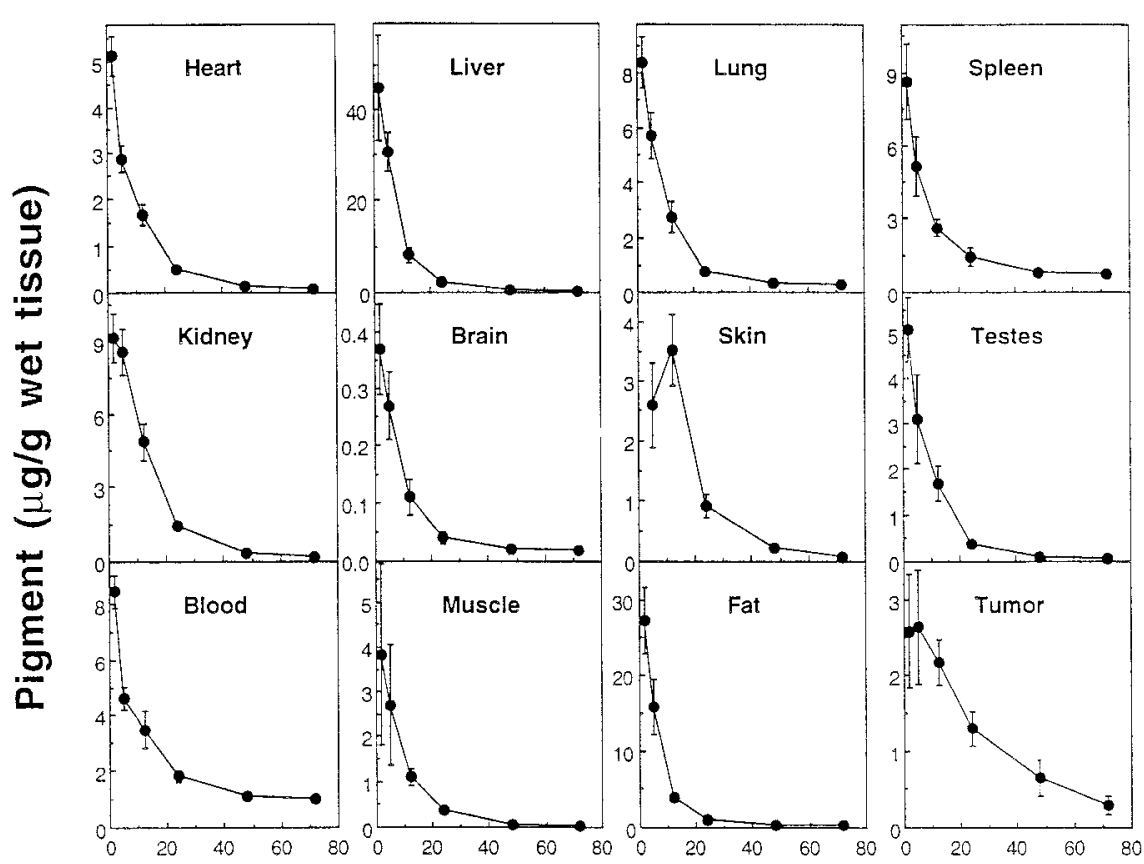

Time after injection $(\mathrm{h})$
Figure 3. Distribution of $\mathrm{Chl}-\mathrm{Ser}$ in mouse tissues at various times after i.p injection. Concentration of ChlSer in tissues of CD 1 nude male mice at different times after injection (six mice for each time point) of $20 \mathrm{mg}$ $\mathrm{Chl}-\mathrm{Ser} / \mathrm{kg}$ body weight. Values represent the mean concentration with standard deviation. and spleen accumulated relatively high concentrations of Chl-Ser, $(9.14,44.7$ and $8.63 \mu \mathrm{g} / \mathrm{kg}$ body weight, respectively) (Table 1), whereas melanoma tumor and brain accumulated low amounts of Chl-Ser $(2.64$ and $0.48 \mu \mathrm{g} / \mathrm{kg}$ body weight, respectively). The high uptake levels of ChlSer in fat tissue $(27.3 \mu \mathrm{g} / \mathrm{kg}$ body weight $)$ are likely to result from the high solubility of the pigment in hydrophobic environments, a result that agrees well with the partition ratio of Ch1-Ser in water: octanol, which we determined to be 1: 9. However, following this argument, higher pigment levels would be expected in the brain. Therefore, the observed low pigment level in the brain $(0.48 \mu \mathrm{g} / \mathrm{kg}$ body weight $)$ probably reflects the combination of the large volume of distri- bution of Chl-Ser, low cerebral blood flow and impermeability of the blood-brain barrier (34).

Clearance of Chl-Ser from the different tissues showed a biphasic kinetic pattern upon semilogarithmic plotting of pigment concentrations as a function of time. The first phase consisted of a relative fast exponential decay where $90 \%$ of the pigment cleared within $40 \mathrm{~h}$ after injection with a halflife $\left(t_{1 / 2}\right)$ in the range of $5-11 \mathrm{~h}$ (Table 1 ). Because only two time points ( 48 and $72 \mathrm{~h}$ ) were recorded in the second phase, no $t_{1 / 2}$ values were calculated. Yet the trend indicated by these two points suggests a much slower clearance rate in the later phase. In contrast we found that within the experimental time interval (up to $72 \mathrm{~h}$ ), the pigment cleared from

Table 1. Time points of peak levels, half-life of clearance and tissue pigment concentrations following i.p. administration of 20 mg Chl$\mathrm{Ser} / \mathrm{kg}$ body weight to $\mathrm{CD} 1 \mathrm{nude}$ male mice

\begin{tabular}{|c|c|c|c|c|c|}
\hline \multirow[b]{2}{*}{ Organ } & \multirow[b]{2}{*}{ Peak $(\mathrm{h})$} & \multirow[b]{2}{*}{$\mathrm{t}^{*}(\mathrm{~h})$} & \multicolumn{3}{|c|}{ Concentration $\div$ ( $\mu \mathrm{g} / \mathrm{g}$ wet tissue) } \\
\hline & & & At peak time: & At $24 \mathrm{~h}$ & At $48 \mathrm{~h}$ \\
\hline Heart & 2 & 7 & $5.12 \pm 0.43$ & $0.49 \pm 0.07$ & $0.15 \pm 0.02$ \\
\hline Liver & 2 & 5 & $44.7 \pm 11.7$ & $2.26 \pm 0.40$ & $0.55 \pm 0.07$ \\
\hline Lung & 2 & 6 & $8.40 \pm 0.95$ & $0.74 \pm 0.09$ & $0.35 \pm 0.10$ \\
\hline Spleen & 2 & 9 & $8.63 \pm 1.56$ & $1.43 \pm 0.35$ & $0.79 \pm 0.17$ \\
\hline Kidney & 2 & 8 & $9.14 \pm 1.02$ & $1.44 \pm 0.07$ & $0.32 \pm 0.04$ \\
\hline Brain & 2 & 7 & $0.48 \pm 0.09$ & $0.04 \pm 0.01$ & $0.02 \pm 0.01$ \\
\hline Skin & 12 & 9 & $3.53 \pm 0.60$ & $0.91 \pm 0.19$ & $0.21 \pm 0.05$ \\
\hline Testes & 2 & 6 & $5.08 \pm 0.72$ & $0.37 \pm 0.08$ & $0.08 \pm 0.02$ \\
\hline Blood & 2 & 11 & $8.43 \pm 0.56$ & $1.81 \pm 0.22$ & $1.09 \pm 0.10$ \\
\hline Muscle & 2 & 7 & $3.83 \pm 2.01$ & $0.38 \pm 0.03$ & $0.05 \pm 0.02$ \\
\hline Fat & 2 & 5 & $27.3 \pm 4.34$ & $1.02 \pm 0.20$ & $0.29 \pm 0.06$ \\
\hline Tumor & 5 & 20 & $2.64 \pm 0.75$ & $1.29 \pm 0.23$ & $0.64 \pm 0.24$ \\
\hline
\end{tabular}

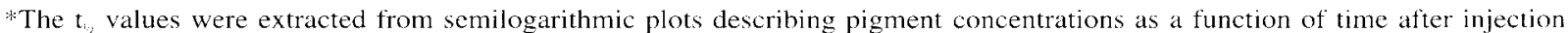
Concentration of Chl-Ser $(\mu \mathrm{g} / \mathrm{g}$ wet tissue) in each tissue is an average of six mice \pm SD.

Peak time indicates the time point for maximum recorded pigment level of each tissue. 
the tumor in a single slow exponential decay with a half-life of $20 \mathrm{~h}$. The longer retention time of Chl-Ser in the tumor compared to the other tissues suggests that in the case of melanoma the relatively high retention time may allow for tissue selectivity in PDT in a way that resembles observations made with HPD (35). The basis for this phenomenon is not clear but could be due to the combination of enhanced permeability of the tumor's vasculature and the possibility that solid tumors that contain necrotic regions may act as a sink. The specific case of melanoma adsorption of the pigment to melanin may further enhance the sink effect.

Although the clearance rates from all tissues (except the tumor) are of the same order of magnitude. the Chl-Ser levels attained vary significantly in each. Thus, at $2 \mathrm{~h}$ after injection only the brain contains a lower pigment concentration than the tumor (see concentration at peak time) (Table 1). However, at $24 \mathrm{~h}$ only the liver, kidney, blood and spleen had higher Chl-Ser levels than the tumor. At the same time the heart, lung, brain, skin, testes, muscle and fat all contained less pigment/gram tissue than the tumor (Table 1). Consequently, the concentration ratio of pigment in the tumor relative to other organs apart from blood showed an apparent increase with time, reaching a maximum $>1$ (for most tissues) at $48 \mathrm{~h}$ after injection. The concentration ratio of pigment in the tumor relative to the blood had peaked at $24 \mathrm{~h}$ after injection.

One of the most important conclusions of this study is that by $72 \mathrm{~h}$ after injection (the longest recorded time), nearly $100 \%$ of the pigment and its metabolites had cleared from all tissues. Bellinier and coworkers determined the distribution and clearance of the $\left[{ }^{14} \mathrm{C}\right]$ radioisotopically-labeled equivalent of Photofrin in DBA/2 Ha-DD mice. They reported retention of $\left[{ }^{14} \mathrm{C}\right]$ activity in the animal tissues for extended time periods ( $>192 \mathrm{~h}$ ) after drug administration where a large part of the radioactivity is accounted to Photofrin (36). Peng and coworkers, using fluorescence methods. reported that the concentration of Photofrin was highest in different organs or tissues of BALB/c nude mice 12-72 $\mathrm{h}$ after injection with clearance half-lives of about $30 \mathrm{~h} \mathrm{(37).}$ Thus the short retention time of Chl-Ser in mouse tissues in both relative and absolute terms may be of great advantage in clinical applications of PDT as compared to Photofrin. The use of Photofrin is presently limited by its very low clearance rates, subjecting patients to severe skin photosensitivity for excessively long periods of time (of the order of weeks to months) after administration of the drug (38).

Two additional experiments with male CDI nude mice were performed. one using 24 males and one using 30 males and 30 females treated with $20 \mathrm{mg} \mathrm{Chl-Ser} / \mathrm{kg}$ body weight. In all three experiments we obtained similar results and no significant differences were observed between males or females. Similar results were also obtained in one experiment performed with 26 C57 black male mice.

\section{Biodegradation of Bchl-Ser}

Spectra (absorption and fluorescence) of acetone extracts obtained after Bchl-Ser administration pointed to lower chemical stability in all tissues when compared to Chl-Ser. The optical absorption spectra of the Bchl-Ser in tissue acetone extracts including those prepared from melanoma tumors de-

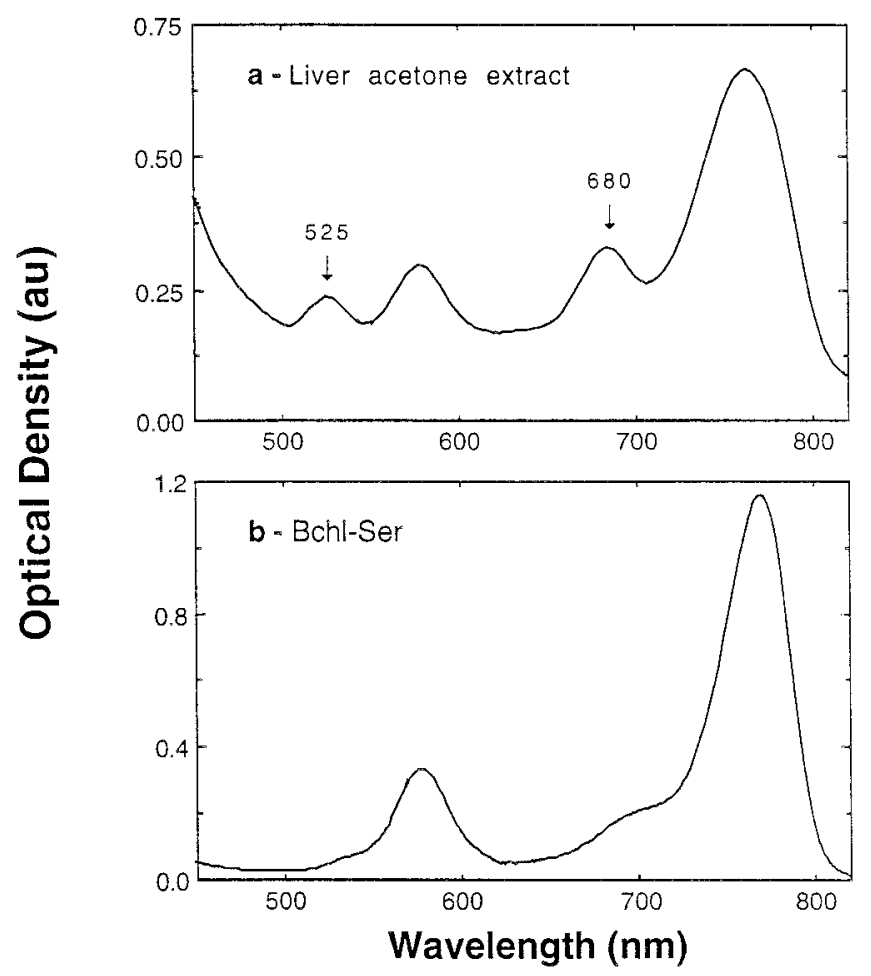

Figure 4. In vivo degradation of Bchl-Ser in mouse liver. Spectra of acetone extracts of (a) mouse liver extract $6 \mathrm{~h}$ after administration of $20 \mathrm{mg} \mathrm{Bchl-Ser} / \mathrm{kg}$ body weight (in $5 \mathrm{~cm}$ cuvette) and (b) 1.62 $\times 10^{-5} \mathrm{M}$ Bchl-Ser (in a $1 \mathrm{~cm}$ cuvette).

picted two additional transitions at $525 \mathrm{~nm}$ and $680 \mathrm{~nm}$ as seen in the depicted liver extract (Fig. 4a). The $525 \mathrm{~nm}$ absorption band characterizes the $Q_{x}$ transition of the demetallized product (Bphe) (39). for which the $Q_{y}$ absorption is at $750 \mathrm{~nm}$ and the fluorescence peaks at $765 \mathrm{~nm}$. The 680 $\mathrm{nm}$ absorption probably results from the presence of oxidation products that fluoresce at $690 \mathrm{~nm}$. A similar phenomenon was previously reported in $\mathrm{DBA} / 2 \mathrm{Ha}$ and $\mathrm{C} 3 \mathrm{H} / \mathrm{HeJ}$ mice for native $\mathrm{Bchl}$ in vivo (8). The content of Bchl-Ser oxidation products in the tissue extracts is expressed in fluorescence units and not in units of concentration as the identity of this material is presently unknown.

\section{Distribution of Bchl-Ser in mouse tissues}

The Bchl-Ser distribution in mouse tissues was studied for time periods ranging from 1 to $16 \mathrm{~h}$ after i.p. injection of 20 mg Bchl-Ser/kg body weight (Fig. 5, Table 2). Most tissues including the melanoma tumor reached peak levels of BchlSer within $\sim 1$ h (tests $2 \mathrm{~h}$. muscle 1-2 h) after injection. By $16 \mathrm{~h}$ after injection (the longest recorded time), nearly $100 \%$ of the pigment had cleared from all tissues.

The time-dependent decline in Bchl-Ser concentration in the different tissues reflects both degradation (to Bphe a and oxidation products) and vascular transport. Thus, during the first $4-6 \mathrm{~h}$ (concerning $65 \%$ of peak pigment levels in the tumor and $90 \%$ in the other tissues) the decline in pigment concentrations could be fitted by the same exponential curve in all tissues. The corresponding $t_{1 / 2}$ values were in the range of $1.5-3 \mathrm{~h}$ (Table 2 ) including the tumor. The residual Bchl- 

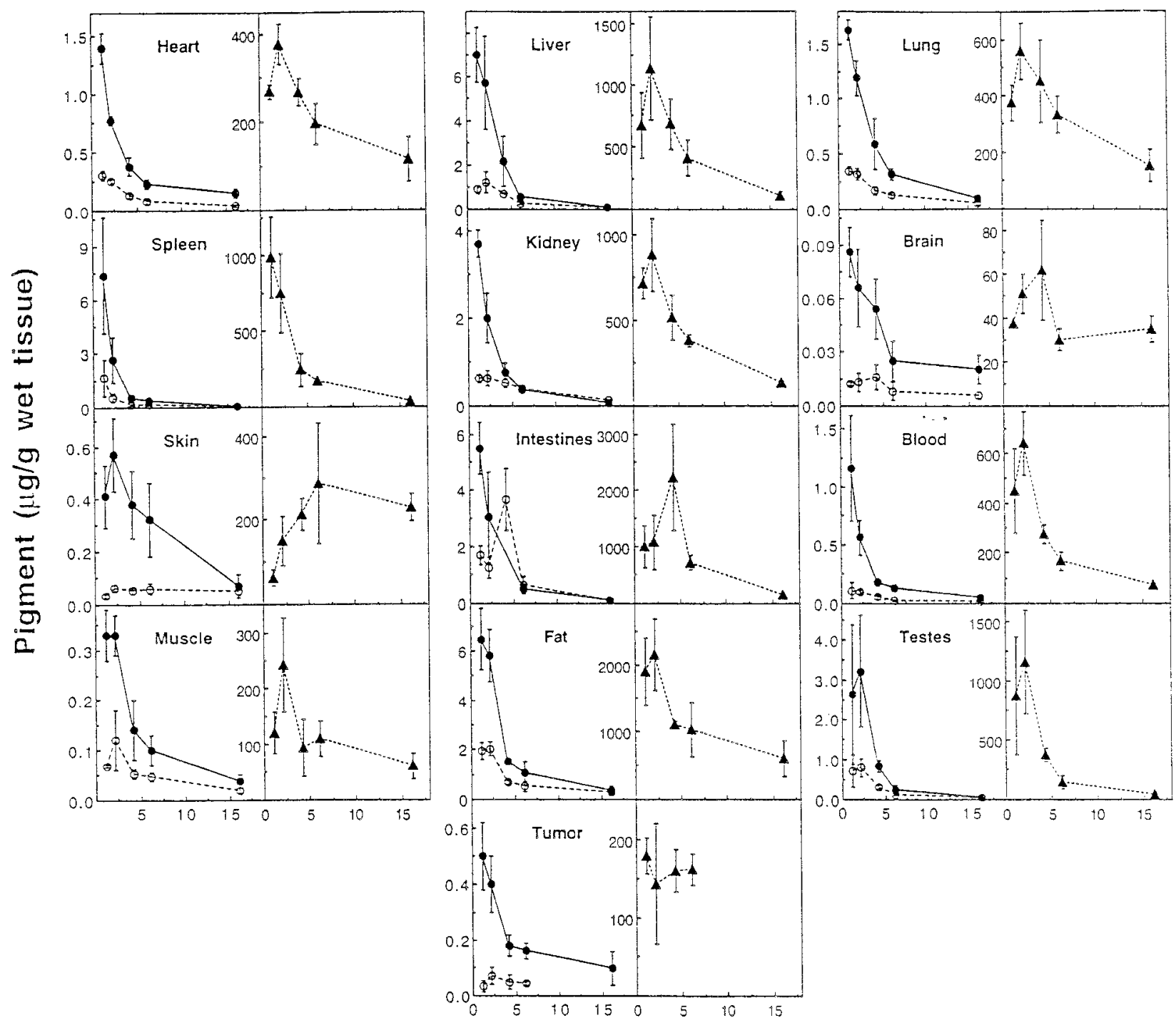

Time after injection (h)

Figure 5. Distribution of Bchl-Ser in mouse tissues at various times after i.p injection. Concentration of Bchl-Ser

Ser $(O-$ 5. (five mice for cach time point) of $20 \mathrm{mg} \mathrm{Bchl-Ser} / \mathrm{kg}$ body weight. Values represent the mean concentration with standard deviation.

Ser $(35 \%$ of peak pigment levels in the tumor and $10 \%$ in the other tissues) seemed to clear much slower.

The peak concentration values of the Bchl-Ser metabolites (Bphe-Ser and oxidation products) vary from 1 to $6 \mathrm{~h}$. Their half-lives in the tumor were $7 \mathrm{~h}$ for the Bphe-Ser and -15 $\mathrm{h}$ for oxidation products, much longer than in other tissues $(2-4 \mathrm{~h}$, Table 2$)$. The reasons for the relatively longer retention times of Bchl-Ser and its photoactive metabolites in the tumor are likely to be similar to those suggested above for $\mathrm{Chl}$-Ser. In addition, like Bchl-Ser, by $16 \mathrm{~h}$ after injection most of the degradation products had cleared from healthy tissues. The Bphe-Ser concentration at early time points (1 h) was found to be relatively low in liver, skin, blood and tumor when compared to intestines, fat, testes and kidney. The differences in the peak time values and relative concentrations of Bphe-Ser are likely to reflect the differences in the nature of the respective tissue, i.e. $\mathrm{pH}_{2} \mathrm{pO}_{2}$, hydropho- bicity, susceptibility to tissue-specific degradation enzymes and the extent of the vasculature.

Two additional experiments were performed on CDI nude mice treated with $20 \mathrm{mg} \mathrm{Bchl-Ser} / \mathrm{kg}$ body weight, one with 12 female and 7 male mice and one involving 24 male mice. The results of these experiments were essentially identical to the one described in Fig. 5 and Table 2.

Chlorophyllous pigments appear attractive for PDT and are superior to the presently used HPD. The shorter retention of these pigment derivatives in the circulation is expected to minimize the serious side effect of cutanous phototoxicity, presently a major drawback of Photofrin-based PDT. Yet, structure/function relationships, in particular, the role of hydrophobicity, have not been fully resolved (11). This paper addresses the cell phototoxicity and biodistribution of hydrophilic novel Chl/Bchl conjugates. Extremely high phototoxicity, short retention times in vivo and simple mode of drug 
Table 2. Time point of peak levels, pigment concentration at peak time and half-life of Bchl-Ser, Bphe-Ser and oxidation products following i.p. administration of $20 \mathrm{mg} \mathrm{Bchl-Ser} / \mathrm{kg}$ body weight to $\mathrm{CD} 1$ nude male mice*

\begin{tabular}{|c|c|c|c|c|c|c|c|c|}
\hline \multirow[b]{2}{*}{ Organ } & \multicolumn{3}{|c|}{ Bchl-Ser } & \multicolumn{3}{|c|}{ Bphe-Ser } & \multicolumn{2}{|c|}{ Oxidation products } \\
\hline & $\begin{array}{c}\text { Peak } \\
\text { (h) }\end{array}$ & $\begin{array}{c}\text { Concentration at } \\
\text { peak time }\end{array}$ & $\begin{array}{l}t_{t} \\
(h)\end{array}$ & $\begin{array}{l}\text { Peak } \\
\text { (h) }\end{array}$ & $\begin{array}{l}\text { Concentration at } \\
\text { peak time }\end{array}$ & $\begin{array}{l}\mathrm{t}_{\mathrm{i}_{2}} \\
(\mathrm{~h})\end{array}$ & $\begin{array}{l}\text { Peak } \\
\text { (h) }\end{array}$ & $\begin{array}{l}\mathrm{t}_{\mathrm{t}_{2}} \\
(\mathrm{~h})\end{array}$ \\
\hline Heart & 1 & $1.40 \pm 0.13$ & 2 & 1 & $0.30 \pm 0.04$ & 2.5 & 2 & 4 \\
\hline Liver & 1 & $7.0 \pm 1.25$ & 1.5 & 2 & $1.22 \pm 0.48$ & 2 & 2 & 3 \\
\hline Lung & 1 & $1.63 \pm 0.09$ & 2 & 1 & $0.35 \pm 0.04$ & 3 & 2 & 6 \\
\hline Spleen & $i$ & $7.37 \pm 3.25$ & 1.5 & 1 & $1.63 \pm 1.0$ & 2 & 1 & 2 \\
\hline Kidney & 1 & $3.71 \pm 0.31$ & 1.5 & $1-2$ & $0.63 \pm 0.18$ & 4 & 2 & 3 \\
\hline Brain & 1 & $0.09 \pm 0.01$ & 3 & 4 & $0.02 \pm 0.01$ & 2 & 4 & 4.5 \\
\hline Skin & 2 & $0.57 \pm 0.14$ & 3 & 2 & $0.06 \pm 0.01$ & 3.5 & 6 & - \\
\hline Intestine & 1 & $5.50 \pm 0.92$ & 1.5 & 4 & $3.67 \pm 1.12$ & 2.5 & 4 & 3.5 \\
\hline Blood & 1 & $1.16 \pm 0.46$ & 1.5 & 1 & $0.11 \pm 0.07$ & 2.5 & 2 & 2 \\
\hline Muscle & $1-2$ & $0.33 \pm 0.05$ & 2.5 & 2 & $0.12 \pm 0.06$ & 3 & 2 & 3 \\
\hline Fat & 1 & $6.47 \pm 1.23$ & 2 & 2 & $2.03 \pm 0.29$ & 2 & 2 & 3.5 \\
\hline Testes & 2 & $3.21 \pm 1.4$ & 1.5 & 2 & $0.84 \pm 0.23$ & 1.5 & 2 & 1.5 \\
\hline Tumor & 1 & $0.5 \pm 0.12$ & 2 & 2 & $0.07 \pm 0.03$ & 7 & 2 & $\sim 15$ \\
\hline
\end{tabular}

*Peak time indicates the time point of maximum recorded pigment level of each tissue. The $t_{\text {t }}$ values were extracted from semilogarithmic plots describing pigment concentrations (or fluorescence) as a function of time after injection. Concentration of the pigments ( $\mu \mathrm{g} / \mathrm{g}$ wet tissue. Bchl-Ser and Bphe-Ser) in each tissue is an average of five mice \pm SD.

delivery of both Chl-Ser and Bchl-Ser in addition to their superior spectral properties are of significant advantage for potential application of these pigments in PDT when compared to Photofrin and the water-insoluble Bchl and Bphe.

The presented results indicate that Bchl-Ser- or Chl-Serbased PDT has to be performed at early time windows, only a few hours following drug administration to coincide with maximal tissue levels of the drug using a weaker light source. Consequently, the entire treatment protocol is expected to become shorter with significant clinical advantages. The reason for the high in vitro photocytotoxicity of Chl/Bchl-Ser compared to the Bphe-methyl esters is presently under study.

Acknowledgements-We thank Asaf Rudich for his devoted help. Y.S. is the incumbent of the Charles and Tillie Lubin chair of Biochemical Endocrinology. This study was supported in part by grants from The Lynne and William Frankel Fund for the Diagnosis and Treatment of Ovarian and Breast Cancer, The Jaffe family founda tion. The Ministry of Science and Technology Israel, the Commission of the European Communities and Yeda Research and Development Co. Ltd. Israel.

\section{REFERENCES}

1. Pandey, R. K., F.-Y. Shiau, A. B. Sumlin, T. J. Dougherty and K. M. Smith (1994) Syntheses of new bacteriochlorins and their antitumor activity. Bioorg. Med. Chem. Lett. 4, 1263-1267.

2. Svaasand, L. O. (1984) Optical dosimetry for direct and interstitial photoradiation therapy of malignant tumors. In Porphyrin Localization and Treatment of Tumors (Edited by D. R. Doiron and C. J. Gomer), pp. 91-114. Liss, New York.

3. Doiron, D. R. (1984) Photophysies and instrumentation for por phyrin detection and activation. In Porphyrin Localization and Treatment of Tumors (Edited by D. R. Doiron and C. J. Gomer), pp. 41-73. Liss. New York.

4. Wilson, B. C., W. P. Jeeves and D. M. Lowe (1985) In vivo and post mortem measurements of the attenuation spectra of light in mammalian tissue. Photochem. Photobiol. 42, 153-162.

5. Amato, I. (1993) Hope for a magic bullet that moves at the specd of light. Science 262, 32-33.

6. Ficdor, L., A. A. Gorman, I. Hamblett, V. Rosenbach-Belkin, Y. Salomon, A. Scherz and I. Tregub (1993) A pulsed laser and pulse radiolysis study of amphiphilic chlorophyll derivatives with PDT activity toward malignant melanoma. Photochem. Photobiol. 58. 506-511.

7. Krasnovskii, A. A.. Jr., I. V. Vichegzhanina, N. N. Drozdova and A. A. Krasnovskii (1985) Generation and quenching of singlet molecular oxygen by bacteriochlorophyll and bacteriopheophytin a and b. Dokl. Akad. Nauk SSSR 283, 474-477.

8. Henderson, B. W.. A. B. Sumlin, B. L. Owezarczak and T. J. Dougherty (1991) Bacteriochlorophyll-a as photosensitizer for photodynamic treatment of transplantable murine tumors. $J$. Photochem. Photobiol. B Biol. 10, 303-313.

9. Henderson, B. W. and G. Farrell (1989) Possible implication of vascular damage for tumor cell inactivation in vivo: comparison of different photosensitizers. Proc. SPIE Int. Soc. Opt. Eng. $1065,2$.

10. Dougherty, T. J. and A. B. Sumlin (1989) Chlorophyll and bacteriochlorophyll as potential photosensitizers in PDT. In Photodynamic Therapy: Mechanisms. Los Angeles. [Abstract]

11. Pandey, R. K.. F.-Y. Shiau, A. B. Sumlin, T. J. Dougherty and K. M. Smith (1992) Structure/activity relationships among photosensitizers related to pheophorbides and bacteriopheophorbides. Bioorg. Med. Chem. Lett. 2. 491-496.

12. Pandey, R. K., S. Constantine, D. A. Goff, A. N. Koryrev, T. J. Dougherty and K. M. Smith (1996) Chlorophyll-a derivatives in photodynamic therapy: effect of position of heptyl ether sidechains on in vivo photosensitizing activity. Bioorg. Med. Chem. Lett. 6, 105-110.

13. Bellnier, D. A., B. W. Henderson, R. K. Pandey, W. R. Potter and T. J. Dougherty (1993) Murine pharmacokinetics and antitumor efficacy of the photodynamic sensitizer 2-[1-hexyloxyethyll-2-devinyl pyropheophorbide-a. I. Photochem. Photobiol. B Biol. 20, 55-61.

14. Lee, S.-J. H., N. Jagerovic and K. M. Smith (1993) Lise of the chlorophyll derivative, purpurin-18, for syntheses of sensitizers for use in photodynamic therapy. J. Chem. Soc. Perkin Trans. I, $2369-2377$

15. Moser, J. G. (1993) Attempts to treat malignant melanoma by photodynamic therapy using bacteriopheophorbide ester as a sensitizer. SPIE Conf. Proc. 1881, 116-125.

16. Hoober. J. K., T. W. Sery and N. Yamamoto (1988) Photody namic sensitizers from chlorophyll: purpurin-18 and chlorin p6. Photochem. Photobiol. 48, 579-582.

17. Spikes, J. D. (1990) Chlorins as photosensitizers in biology and medicine. J. Photochem. Photohiol. B Biol. 6, 259-274.

18. Kessel, D. and K. Smith (1989) Photosensitization with derivatives of chlorophyll. Photochem. Photobiol. 49. 157-160.

19. Röder, B. (1990) Photosensitizing properties of phorbides. $J$. Photochem. Photobiol B Biol 5, 519-521. 
20. Schers, A., Y. Salomon and L. Fiedor (1994) Chlorophyll and bacteriochlorophyll derivatives, preparation and pharmaceutical compositions comprising them as photosensitizers for photodynamic therapy. Chem. Abst. 120,386

21. Tregub. I.. J. Schmidt-Sole, J. DeJordy, V. Rosenbach-Belkin, V. Brumfeld, L. Fiedor, Y. Salomon and A. Scherz (1992) Application of chlorophyl and bacteriochlorophyll derivatives to PDT of malignant melanoma. In Proceedings of the Second lnternational Congress on Interaction of Light with Biological Systems (Edited by M. Holick and A. Kligman), pp. 354-361. W. de Gruyter. New York.

22. Zilberstein, J., A. Scher, A Brombers, P. Bendel, M. Necman and Y. Salomon (1994) Chlorophyll based PDT of melanoma follow up by MRI and by tissue inserted oxygen sensor. In abstract book of the conference: The Tumor Microemironment: Its Charactertation, Modification and Clincal Implication. Faculty of Medicine. University of Granada. Granada. Spain.

23. Zilberstein, J., A. Scher ., A. Bromberg, P. Bendel. M. Neeman and Y. Salomon (1995) Mechanisms involved in chlorophyll based photoinduced cell damage: photodynamic therapy of melanoma. Proc. Soc. Magn. Reson. 3. 1681 .

24. Amir-Shapira, D., E. E. Goldschmidt and A. Altman (1987) Chlorophyll catabolism in senescing plant tissues: in vitro breakdown intermediates suggest different degradative pathways for citrus fruit and parsley leaves. Proc. Natl. Acad. Sai. USA 84. $1901-1905$.

25. Fiedor. I. (1994) Modified chlorophylls as models for primary photosynthesis and photosensitizers for photodynamic therapy of cancer. Ph.D. Thesis, Weizmann. Institute of Science. Re hovot, Israel.

26. Gerst. J. E., J. Sole. J. P. Mather and Y. Salomon (1986) Regulation of adenylate cyclase by $\beta$-melanotropin in the $\mathrm{M} 2 \mathrm{R}$ melanoma cell bine. Mol. Cell. Endorinol. 46, $137-147$.

27. Yeh. C.-J. G.. B.-I. Hsi and W. P. Faulk (1981) Propidium iodide as a nuclear marker in immunofluorescence. II. Wse with cellular identification and viability studies. I. Immunol. Methods 43, $269-275$

28. Chen, L., Y. Mory, A. Zilberstein and M. Revel (1988) Growth inhibition of human breast carcinoma and leukemia/lymphoma cell lines by recombinant interferon. Proc. Nat. Acad. Scit. USA 85. $8037-8041$.

29. DeJordy, J. O.. P. Bendel, A. Horowitz, Y. Salomon and H. Degani (1992) Correlation of MR imaging and histologic findings in mouse melanoma. J. Magn. Reson. Imag. 2. 695-700.

30. Moser, J G A Ostrowsky M. Gümüsdagli and B Kleiber (1994) Bacteriopheophorbide esters: photosensitizers without "threshold dose"? EUROPTO Conf. Proc. 2078, 193-204.

31. Hoff, A. J and J. Amesz (1991) Visible absorption spectroscopy of chlorophylls. In Chlorophy/ls (Edited by H. Scheer), pp. 723738. CRC Press. Boca Raton. FL.

32. Dougherty. T. J. (1992) Photochemistry in the treatment of cancer. Adr. Photochem. 17, 275-311.

33. Henderson. B. W. and T. 1. Dougherty (1992) How does photodynamic therapy work? Photochem. Photobiol. 55. 145-157.

34. Benet, L. Z.. J. R. Mitchell and L. B. Sheiner (1991) General principle. In Goodmen and Gilman's The Pharmacological Basis of Therapeutics (Edited by A. G. Gilman, T. W. Rall, A. S. Nies and P. Taylor), pp. 10-11. McGraw-Hill, New York.

35. Pantelides M. L. J V. Moore and N. J. Blavklovk (1989) A comparison of serum kinetics and tissue distribution of Photofrin II following intravenous and intraperitoneal injection in the mouse. Photochem. Photobiol. 49,67-70.

36. Bellinier, D. A.. Y.-K. Ho, R. K. Pandey. J. R. Missert and T. $J$ Dougherty (1989) Distribution and elimination of Photofrin II in mice. Photochem. Photobiol. 50, 221-228.

37. Peng, Q.. J. Moan. M. Kongshaug. J. F. Evensen. H. Anholt and $C$. Rimington (1991) Sensitizer for photodynamic therapy of cancer: a comparison of the tissue distribution of Photofrin II and aluminum phthalocyanine tetrasulfonate in nude mice hearing a human malignant tumor. Int. J. Cancer 48, 258-264.

38. Bellinier, D. A. and T. J. Dougherty (1989) Protection of murine foot tissuc and transplantable tumor against Photofrin-II-mediated photodynamic sensitization with WR-2721.J. Photochem. Photobiol. B Biol. 4, 219-225.

39. Scheer. H. (1991) Structure and occurrence of chlorophylls. In Chlorophylls (Edited by H. Scheer), pp. 3-30. CRC Press, Boca Raton, FL. 